sciendo Порівняльна професійна педагогіка 9(2)/2019 Comparative Professional Pedagogy 9(2)/2019

DOI: $10.2478 /$ rpp-2019-0021

Postgraduate, LOLITA VOROBIOVA Ivan Ziaziun Institute of Pedagogical and Adult Education NAPS of Ukraine Address: 9 M. Berlynskyi St., Kyiv, 04060, Ukraine E-mail: lolitalolita@ukr.net

\title{
AMERICAN EXPERIENCE OF THE DALTON PLAN IN THE DUTCH SCHOOLING
}

\begin{abstract}
This article presents the results of scientific-pedagogical research, which consisted in analyzing the American experience of the Dalton plan in the schooling of the Netherlands, the ranking surveys according to strict criteria, and the implementation of an adapted version of the original American pedagogical model of the Dalton Plan in the schooling of Holland; characterizing the features of the introduction of the Dalton Plan into the Dutch educational systems. While researching the works of M. Montessory, H. Parkhurst and D. Lager, had been examined as the main source of the study. The archival documents of the biggest collection of Helen Parkhurst papers of the Archive of University of Wisconsin Stevens Point had been analyzed. It was studied that American experience of the Dalton Plan is top ranked among private institutions of the country. It is obvious that after the United States, the country of the Dalton Plan origin, the continental Europe and Holland have a dominant position regarding the implementation of the Dalton plan in the educational systems. It is stated that schools implementing the Dalton Plan are united in recognizing the fact that such a pedagogical model ensures the development of the student's individuality and his social experience. The special advantage the Dalton students obtain is the ability to use different approaches and sources in seeking information that is necessary for the organization and achievement of their own research. The ideas of the Dalton Plan can be justified in the light of modern theory and research. The Dalton Plan was successfully implemented into the primary and secondary schools of the Netherlands ranked the counrty $11^{\text {th }}$ in the world education survey. The Dalton Plan philosophy became one of the components of the complicated Dutch educational system.
\end{abstract}

Key words: the Dalton plan, American model, individual education, Dutch schooling.

\section{АНОТАЦІЯ}

У статті автором представлені результати науково-педагогічних досліджень, які полягали в аналізі американського досвіду Дальтон плану в освіті Нідерландів, показників рейтингових оцінок Дальтон-иколи, проведених за суворими критеріями провідними американськими виданнями та характеристииі особливостей впровадження адаптованої версії оригінальної американської педагогічної моделі Дальтон плану в освіту Голландії. Під час дослідження було розглянуто роботи Марії Монтессорі, Хелен Пархерст і дисертаиійне дослідження Діани Лагер. Проаналізовано архівні документи найбільшої колекиії документів Х. Паркхерст архіву Університету Вісконсину Стівенс Пойнт. Було зазначено, що американський досвід Дальтон плану за рейтинговими оиінками має найвищі показники серед приватних установ Сполучених Штатів. Очевидно, що після США, краӥни походження Дальтон плану, континентальна Європа і Голландія займають друге місие щодо реалізаиії Дальтон 
8 sciendo Порівняльна професійна педагогіка 9(2)/2019 Comparative Professional Pedagogy 9(2)/2019

плану в освітніх системах. Зазначається, щь школи, які практикують Дальтон план, єдині у визнанні того факту, щзо така педагогічна модель забезпечує розвиток індивідуальності студента та його соціального досвіду. Значна перевага, яку отримують студенти Дальтона, полягає в можливості використовувати різні підходи та джерела в пошуку інформаиії, необхідної для організаиії та досягнення власних досліджень. Така характерна риса виокремлює Дальтон студентів, особливо в умовах дистаниійного отримання освіти. Ідеї Дальтон плану можуть бути виправдані у світлі сучасних теорій $і$ досліджень. Дальтон план був успішно впроваджений у початкові та середні школи голландської освітньої системи, яка посіла 11 місие у світі за результатами обстеження освіти. Філософія Дальтон плану стала однією зі складових освітньої системи Нідерландів.

Ключові слова: Дальтон план, американська модель, індивідуальне навчання, освіта Нідерландів

\section{INTRODUCTION}

The idea of the equal access to the basic values of a post-industrial society is the basis of the new information era. A particular citizen is considered as the main component of this type of society. Education is no longer a means of mastering the system of readymade, generally accepted knowledge. It is forced to change, becoming a strategic factor that results in the productive assimilation of the personality of a large stream of information.

The innovative idea of the Dalton Plan is based on the principle of the individual development of students. Schools implementing the Dalton Plan are united in recognizing the fact that such a pedagogical model ensures the development of the student's individuality and his social experience. The special advantage the Dalton students obtain is the ability to use different approaches and sources in seeking information that is necessary for the organization and achievement of their own research. The difference between Dalton students and students from traditional educational institutions is that the former do not need to be rebuilt for study without a mentor, tutor. It results in adapting to the conditions of education that researchers see in the future, namely, education at online courses. The online education system is just emerging. Yet due to the fact that the leading universities practice the online schooling widely, the online form of education is rapidly developing and improving. Consequently, the Dalton Plan is valuable in its approach to educating students in their responsibility for self-education, self-development.

From the point of view of socialization, after studying according to the Dalton philosophy, society, as a result, receives a citizen with a prevailing social consciousness; he is trained to work effectively not only as an independent unit, but also in the context of the community to which it belongs, directed towards its development.

Experimenting with alternative forms of learning organization led to the fact that Dalton's plan was recognized as an effective form of organization of learning activities and introduced not only in the country of its origin, but also far beyond the borders of the United States. It is obvious that continental Europe has a dominant position regarding the implementation of the Dalton plan in the educational systems. Such countries as Great Britain, the Netherlands, Finland pioneered in the introducing this pedagogical model. Therefore, they have many years of experience in applying either the Dalton Plan or some of its elements in pre-school and school education.

\section{THE AIM OF THE STUDY}

The aim of the study is to analyze the implementation of an adapted version of the original American pedagogical model of the Dalton Plan in the foreign schooling; to 
sciendo Порівняльна професійна педагогіка 9(2)/2019 Comparative Professional Pedagogy 9(2)/2019

characterize the features of the introduction of the Dalton Plan into the foreign educational systems.

\section{THEORETICAL FRAMEWORK AND RESEARCH METHODS}

The research relies extensively upon the comparative analysis and synthesis as the basic traditional methods of studying reality in the historical research; the archival research comprises the analyzing of the existing data, such as archival documents of the Archive of University of Wisconsin Stevens Point, the biggest collection of Helen Parkhurst papers; the descriptive method is used for the study and description of official documents, scientific and pedagogical sources; the cycles had been studied by the historical method and analytical methods. While researching the works of M. Montessory, H. Parkhurst and D.Lager, had been examined as the main source of the study.

\section{RESULTS}

In 1919, after testing the Dalton Laboratory Plan at school in Dalton, using the financial support of prominent businessmen Helen Parkhurst opened her own school in New York, USA. The Dalton School, which became the founder of the Dalton Plan methodology, is located in East Side, Manhattan. Since the very first years of its foundation, the school has had a tremendous success. Teachers from all over the world came to study Parkhurst' Plan. As The Dalton Plan gained popularity, it soon became apparent the need for significant expansion.

The school has been known for a hundred years as a constructivist elite private school, which is considered one of the most innovative models of education reform. The Dalton School remains an example of the perception of a bold vision of a new, progressive American approach to education. As a result of the rating of well-known American analytical publications, Dalton School, as a prestigious private educational institution, takes places at the top lists (see Table 1).

Table 1

Rating results of the Dalton School among private US institutions (2003-2018)

\begin{tabular}{|c|c|c|c|c|}
\hline № & Year & Place & $\begin{array}{c}\text { Publishing } \\
\text { company }\end{array}$ & Reference \\
\hline 1 & 2003 & $3^{\text {rd }}$ from 65 & Worth & http://www.worth.com/the-new-school/ \\
\hline 2 & 2003 & $8^{\text {th }}$ from10 & $\begin{array}{c}\text { Wall Street } \\
\text { Journal }\end{array}$ & $\begin{array}{c}\text { http://webreprints.djreprints.com:80/ } \\
\text { wsj_tuition_040104.pdf }\end{array}$ \\
\hline 3 & 2010 & $13^{\text {th }}$ from 55 & Forbes & $\begin{array}{c}\text { https://www.forbes.com/pictures/f145mj/ } \\
\text { americas-best-prep-sc/\#367ff2134ea0 }\end{array}$ \\
\hline 4 & 2014 & $10^{\text {th }}$ from 25 & Business Insider & $\begin{array}{c}\text { https://www.businessinsider.com/best- } \\
\text { private-high-schools-america-2014-11 }\end{array}$ \\
\hline 5 & 2018 & $\begin{array}{c}5^{\text {th }} \text { from } \\
8000\end{array}$ & Niche & $\begin{array}{c}\text { https://www.niche.com/k12/search/best- } \\
\text { private-high-schools }\end{array}$ \\
\hline
\end{tabular}

So, it goes without saying that The Dalton School is one of the top elite private schools in New York City.

The ratings of the US private schools comprised strict criteria, according to a thorough analysis of data from the US Department of Education regarding test scores received, data from colleges on the number of students enrolled in private schools, feedback from parents and students about the educational environment of educational institutions. So, 
sciendo Порівняльна професійна педагогіка 9(2)/2019 Comparative Professional Pedagogy 9(2)/2019

it is obvious that the Dalton School has occupied one of the dominant positions among the private educational institutions of the country since the last century.

The Dalton School in New York is positioning itself as one of the best educational institutions to prepare for the entry into the leading universities of the USA. According to well-known American analytical publications, $100 \%$ of the Dalton graduates enter colleges every year (Worth, 2003), (Wall Street Journal, 2003), (Forbes, 2010), (Business Insider, 2014). The school provides an environment in which students are actively involved in the learning process, gaining knowledge through their own experience and primary sources. Academically strong, intellectually inquisitive, independent in beliefs, and most importantly independent and interested in exploring a new, such characteristic, according to L. Stiller, a former assistant to the director of a senior school of educational work, give university lecturers to those students who completed Dalton.

Almost a century ago Helen Parkhurst, originator of the Dalton Plan and founder of the Dalton School in New York, visited many countries. She was propagating the Dalton plan among the pedagogical community. Her lectures, pedagogical seminars, radio program cycles, speeches at meetings, exhibitions, parenting meetings took place during the favorable climate of the time (Lager, 1983). The progressive educators were interested in experimenting with alternative forms of learning organization. It led to the fact that the Dalton plan was recognized as an effective form of learning organization. Parkhurst's ideas were adopted in other countries. They were implemented not only in the country of its creation, but also far beyond the borders of the United States.

During the life H. Parkhurst was recognized internationally. H. Parkhurst was awarded with gold medals, received honors in 1937 from the Emperor of Japan and the Presidents, (Archives of Stevens Point, 1937). In 1925, she was presented to the awards first president of the Chinese republic. In 1957, the Queen of the Netherlands, Juliana, awarded H. Parkhurst the Order of Orange-Nassau for the significant contribution and influence on the education of the Netherlands.

Continental Europe has a dominant position regarding the implementation of the Dalton plan into the educational system. Such countries as Great Britain, the Netherlands and Finland were the first to introduce such a technique; therefore, these countries have many years of experience in applying not only the Dalton Plan but also some of its elements in pre-school and school education. Parkhurst's 1924 reception in Japan also provides an example of the Dalton Plan abroad (Archives of Stevens Point, 1924).

The educational system in the Netherlands is characterized by innovation, democracy, openness and affordability. In 2008, education in the Netherlands ranked 9th among the best educational systems in the world according to the Program for International Student Assessment (PISA), developed by the Organization for Economic Co-operation and Development (OECD). In 2017, after adding 5 new key indicators to the assessment system, the Netherlands ranked $11^{\text {th }}$ in the world's ranking of education with a score of 67 , leaving behind countries such as Belgium (65), Germany (63), France ( 50) and the United States (47) (OESD.org, 2019).

A considerable number of elementary schools in the Netherlands are mostly based on a certain educational philosophy. In Holland, the extremely popular is the Montessori Method, the Dalton plan, the Pestalozzi plan and the Jena plan. Most of these schools are state-owned, but some special schools can also support one of the above-mentioned educational philosophies. 
sciendo Порівняльна професійна педагогіка 9(2)/2019 Comparative Professional Pedagogy 9(2)/2019

At the beginning of the last century, the country began to introduce the latest approaches to the organization of the educational system. In 1917, Maria Montessori visited the country for the first time. The first Montessori society was founded there. A meeting with Hugo de Vries, Professor of Biology at the University of Amsterdam was crucial. The acquaintance with his studies of "sensitive periods" influenced M. Montessori. De Vries's discovery of animals' of special periods characterized by the highest susceptibility during which the animals acquired the necessary knowledge, skills and patterns of behavior were reflected in the pedagogical work of M. Montessori, since the teacher observed the same phenomena in children.

After the Second World War, the teacher settled in the Kingdom of the Netherlands, where she spent the rest of her life. The foregoing explains the popularity of the Montessori method in this country.

In the pedagogical practice of the Netherlands after the Montessori method the second place in popularity is occupied by schools, the educational process of which is in accordance with the principles of the Dalton plan.

Early last century the Dutch commission visited the Dalton Schools in England. As a result in 1928 the first Dalton School for Girls appeared in Holland.

The war damage and the baby boom after the liberation led to the construction of various emergency schools in Rotterdam around 1950. Shortly after the Second World War, in 1952, H. Parkhurst visited the Netherlands. She was invited by the headmaster, Van der Geer, his team and the parent committee. It was made the decision to name the school after the founder of Dalton education. Such recognition is usually bestowed after one is dead, wrote Parkhurst (Parkhurst, 1952). She felt honored and after correspondence she decided to come and take a look. She wrote to the Dalton School that it should not be a holiday trip and she liked a heavy program (Archives of Stevens Point, 1957). So, the Dalton school in Rotterdam conceived the name of Helen Parkhurst.

The development of schools in accordance with Dalton's pedagogical principles is that they are based on the principles of freedom, cooperation. The most important characteristic that distinguishes the Dalton Plan is a managed budget of time. This feature is equally acceptable for work of teachers, parents and students. This Dalton Plan concerns freedom in the organization of the school, the choice of an educational concept, cooperation with other institutions, etc.

At primary schools in Holland, we see the introduction and development of the Dalton Plan, which in this educational system is called the sub-Dalton plan. Thus, at the beginning of the twentieth century the reformist sentiment in pedagogy did not stop at the critique of the "old" schools, but also contributed to the emergence of "new" educational models and schools.

\section{CONCLUSIONS}

Thus, at the beginning of the twentieth century Holland was in the mainstream of the reformist sentiment in pedagogy. The Dutch educators criticizing the "old" schools had been practicing with some educational implications. It resulted in the emergence of "new" educational models and schools. The Dalton Plan was successfully implemented into the primary and secondary schools. The Dalton Plan philosophy as one of the components of the complicated Dutch system brings the American style of innovation into education, ranking the country $11^{\text {th }}$ in the world's ranking of education, leaving behind countries such as Belgium, Germany, France and the United States. It is obvious that the American experience of the implementing the Dalton School philosophy into Dutch system of 
sciendo Порівняльна професійна педагогіка 9(2)/2019 Comparative Professional Pedagogy 9(2)/2019

primary schooling is fruitful. The present obscurity of the Dalton Plan among the Ukrainian educators is obvious. At present there is little experience and information about the peculiarities of the practicing the Dalton Plan in the Ukrainian schooling, in connection the further scientific research of this issue is beyond doubt.

\section{REFERENCES}

1. Business Insider. (2018). Retrieved from https://www.businessinsider.com/

2. Dalton Visie. (2018). Retrieved from http://daltonvisie.nl.

3. Japan Tour Photograph Album. (ca.1924-1950). Helen Parkhurst Papers (Photo Lots, Lot 18), University of Wisconsin Stevens Point Archive, Stevens Point, WI.

4. Lager, D. (1983). Helen Parkhurst and the Dalton plan: the life and work of an American educator. (PhD. thesis). The University of Connecticut, New York.

5. Organization for Economic Cooperation and Development. (2018). Retrieved from http://www.OESD.org.

6. Parkhurst, H. (1922). Education on the Dalton plan. New York, NY: E.P. Dutton and Company.

7. Parkhurst, H. (1957). Memorabilia [the Order of the Oranje-Nassau (medal with case)]. Helen Parkhurst Papers (Collection 5, Box 14), University of Wisconsin Stevens Point Archive, Stevens Point, WI.

8. Parkhurst, H. (n.d.). Memorabilia [Medal with case (Chinese/Japanese?)]. Helen Parkhurst Papers (Collection 5, Box 14), University of Wisconsin Stevens Point Archive, Stevens Point, WI.

9. Tokaoko Educational Society Photograph Album. (ca.1924-1950). Helen Parkhurst Papers (Photo Lots, Lot 16), University of Wisconsin Stevens Point Archive, Stevens Point, WI.

10. The Forbes. (2018). Retrieved from https://www.forbes.com.

11. The survey ranking schools (2003, September). Your tuition dollars at work. Retrieved from http://webreprints.djreprints.com:80/wsj tuition_040104.pdf.

12. The Worth. (2018). Retrieved from http://www.worth.com/the-new-school/. 